\title{
施工時の損傷レベルがHDPEジオグリッドの 引張強度特性に及ぼす影響
}

\author{
松野 剛 ${ }^{1} \cdot$ 宮田喜壽 ${ }^{2} \cdot$ 平川大貴 ${ }^{2}$
}

粒状土中にHDPEジオグリッドを配置し締固め荷重を与えることで準備した損傷供試体の引張り強度特性を 調べた。損傷レベルをレーザ変位計で測定した供試体の表面粗度をもとに評価した。引張り試験における供 試体のひずみ解析には画像解析技術を用いた．損傷レベルがHDPEジオグリッドの引張強度特性の及ぼす影響 を統計的に考察した。本研究の成果はジオグリッドの設計引張強さの評価法の合理化に貢献する.

キーワード : ジオグリッド，引張強度特性，施工時の損傷

\section{1.はじめに}

補強土壁の設計では，補強材への作用力（補強材力） $T_{\max }$ の設計值と補強材の設計引張強度 $T_{\mathrm{d}}$ をもとに, 製品 の選定と敷設条件の決定を行う． $T_{\mathrm{d}}$ の評価は，製品基淮 強度 $T_{\mathrm{ult}}$ をもとに, 補強材のクリープ特性, 而損傷性, 耐薬品性を考慮して決定するのが一般的であり, 設計に おいて重要な位置づけにある。

補強土壁の設計法は安全率を用いる許容応力度設計法 から部分安全係数を用いる限界状態設計法一移行してい る. 代表的な補強土壁の設計法における補強材の土中破 断に関する照査の概略と設計引張り強度の評価法を表-1 に示す．同表には限界状態設計法である AASHTO ${ }^{1)}$ ，BS 2), Geoguide ${ }^{3)}$ ，許容応力度設計法である土研センターマ ニュアル ${ }^{4}$ における設計照査の基本的考え，各国の製品 評価プログラム : $\mathrm{NTPEP}^{5)}, \mathrm{BBA}^{\text {6) }}, \mathrm{HKSAR}^{7}$ ，土研セン ター8)で決定される設計強度評価のための各種係数の違
いを示した．設計法は信頼性ベースの限界状態設計法が 主流になっているが，その設計概念に合致する補強材の 設計引張強度 $T_{\mathrm{d}}$ の評価法は確立されていない状況にあ る. その確立にむけた基礎的検討が必要である.

以上の考えにもとづき，著者らは施工時の損傷の影響 の評価法について検討した.この問題については, Allen et. $\mathrm{al}^{\text {9) 10) }}$, Elias et .al. ${ }^{11,2)}$, Hufenus et. $\mathrm{al}^{13)}$ ，そして Huang et.

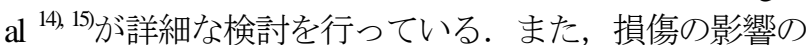
評価法について, ASTM D5818 ${ }^{16}$ や ISO $10722{ }^{17 か ゙ か ゙ 丨 ら ~}$ れている. 表-1 に示した 4 つの評価プログラムでは, 所定の条件で供試体を損傷させ引張試験を行い，損傷供 試体の引張強度と損傷無し供試体の引張強度の比で係数 を決める。しかし，損傷供試体の準備方法は異なってお り，統一的な損傷の影響の評価法を確立する必要がある。 本論文では，施工時の損傷に関する評価法の確立を目指 した室内試験の結果を報告し，損傷の影響を評価する方 法を新しく提案する。

表-1＼cjkstart代表的な補強土壁の設計法における補強材の土中破断に関する照査の概略と設計引張り強度の評価法

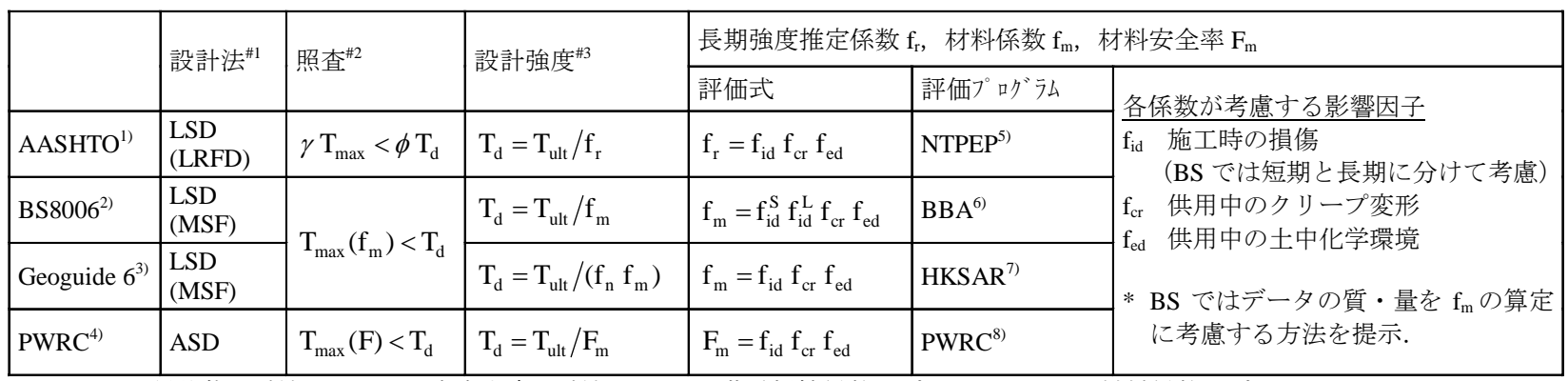

\#1 LSD : 限界状態設計法, ASD : 許容応力度設計法, LRFD : 荷重抵抗係数アプローチ, MSF : 材料係数アプローチ

\#2 $\mathrm{T}_{\text {max }}$ : 補強材への作用力, $\mathrm{T}_{\mathrm{d}}$ : 補強材の設計強度, $\gamma$ or $\phi:$ LRFD における荷重・抵抗係数, $\mathrm{f}_{\mathrm{m}}$ : 材料係数, $\mathrm{F}$ : 安全率

\#3 $\mathrm{f}_{\mathrm{r}}$ : 設計耐用年数における補強材強度を推定するための係数, $\mathrm{f}_{\mathrm{n}}$ : 構造物の耐用年数や経済効果を考慮して決定する部分安全係数, $\mathrm{f}_{\mathrm{m}}$ : 設計補強材強度の余裕度を確保寸るための材料係数， $\mathrm{F}_{\mathrm{m}}$ ：設計補強材強度の余裕度を確保するための材料安全率

1学生会員，防衛大学校＼cjkstart建設環境工学科（恧239-8686 横須賀市走水1-10-20)

2正会員，防衛大学校＼cjkstart建設環境工学科（广239-8686＼cjkstart横須賀市走水1-10-20） 


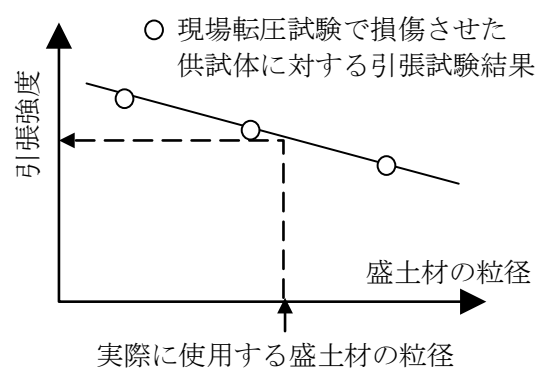

(a) ASTM D5818 ベースで評価する方法

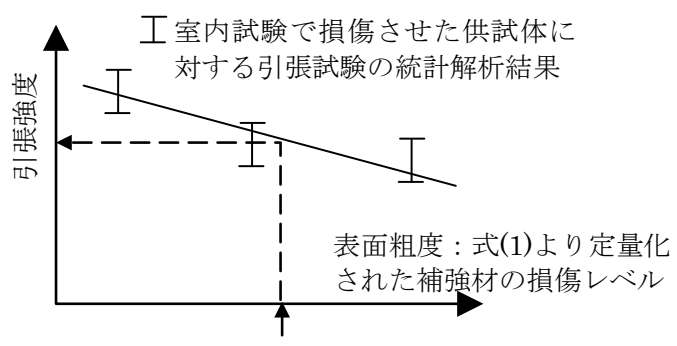

所定の現場条件（盛土材の粒径，締固め条件）に 対して予想される損傷レベル

(b) 本研究で確立を目指している方法

図-1 旧来の評価法と本研究の狙い

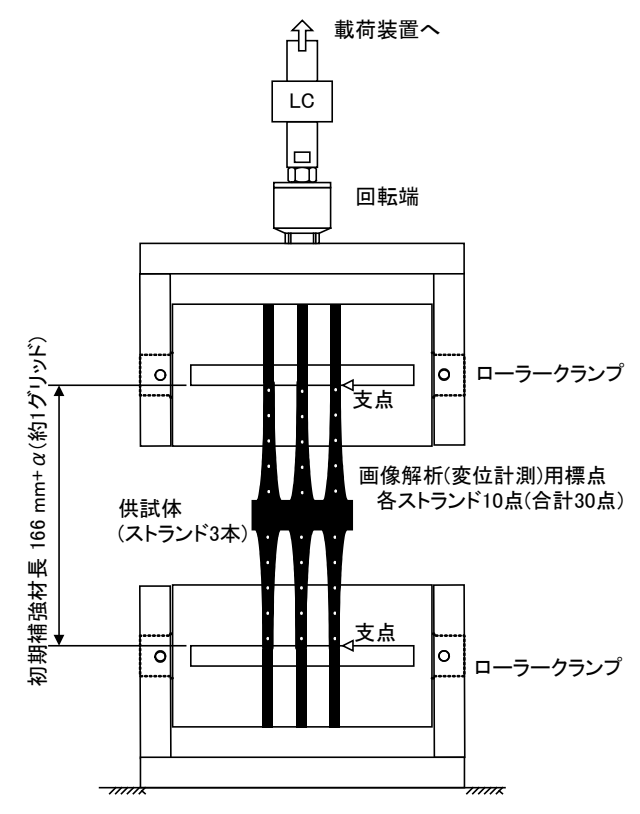

図-2 引張試験条件

\section{2. 実験概要}

\section{（1）研究の狙いと実験概要}

損傷の影響による引張強度の低下を推定する方法とし て, 現場転圧試験によって準備した損傷供試体 ${ }^{16}$ の引張 試験結果を用いる方法と, 室内試験によって準備した損 傷供試体 ${ }^{17}$ の引張試験結果を用いる方法がある. 現場試 験による方法では, 図-1 に示すように，複数の盛土材 でデータを取得しておき，各工事では実際に使用する盛

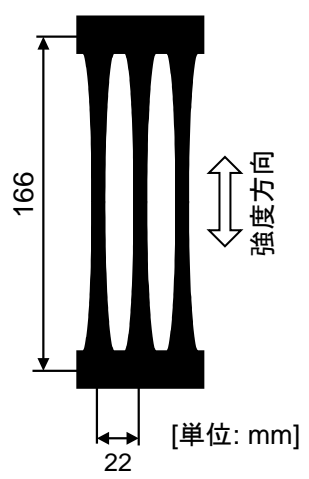

図-3 供試したHDPE ジオグリッドの形状

土材の粒径をもとに補強材の強度低下を評価する．これ に対し, 本研究では, 供試体の損傷レベルをジオグリッ ドの表面粗度解析より定量化し，その結果をもとに補強 材の強度低下を評価することを目指している，そして， 強度低下の評価に，統計解析を導入することを目指して いる．これによって，盛土材の粒径だけで説明できない 損傷の影響を考慮することが可能になり，損傷というば らつきを伴う現象の整理を合理的に行うことができるよ うになると考えられる．以上のことをふまえ，本研究で は，締固め条件を変化させて準備した損傷供試体（損傷 なしも含む）に対し引張試験を実施し，表面粗度解析で 定量化された損傷レベルと引張強度特性を表す評価値の 関係について統計的に考察した. 以下，引張試験と供試 体，損傷供試体の準備方法と実験ケース，供試体の表面 粗度解析法について説明する.

\section{（2）引張り試験と供試体}

引張試験の条件を図-2 に示す。一連の実験では，ネ ッキングの影響を取り除くため，ストランド 3 本（試験 体幅約 $50 \mathrm{~mm}$ ) で弓張試験を実施した. 試験体長さは 1 グリッドと統一した，供試体のつかみ具には，つかみ具 付近での補強材の破断（チャック切れ）が生じにくく, ストランドと平行な方向に均一に張力を負荷できるとい う利点を考慮して，ローラークランプを用いた。 補強材 に生じる引張力 $T$ は, クランプと載荷装置の間にひずみ ゲージ式荷重変換器を設置して計測した. 補強材の伸び ひずみは，CCD カメラで撮影した供試体表面の標点の 動きを画像解析することで算出した。標点数は各ストラ ンド 10 点, 計 30 点とし，初期長を 1 グリッド長として 各ストランドについて算出した伸びひずみの平均值を計 測值とした。 一連の画像解析において，3×3のメディア ンフィルタでノイズ除去を行い，重心座標計測法で標点 の時刻歴を求めた。 引張試験のひずみ速度は，1\%/min とした．室温は $23+2^{\circ} \mathrm{C} の$ 条件を確保した.

一連の実験には，高密度ポリエチレン製の一軸延伸夕 イプのジオグリッド(以下，HDPE ジオグリッド)を用い た。形状は図-3 に示すとおりである。ひずみ速度 $1 \% / \mathrm{min}$ を基準に算出された製品基準強度 $T_{\text {ult }}$ は $50.0 \mathrm{kN} / \mathrm{m}$ である。 
表-2 損傷供試体の準備時の締固め条件

\begin{tabular}{|l|c|c|c|c|}
\hline Damage Level & 1 & 2 & 3 & 4 \\
\hline モールド質量 $[\mathrm{kg}]$ & \multicolumn{5}{|c|}{2.5} \\
\hline 落下高さ $[\mathrm{cm}]$ & \multicolumn{5}{|c|}{10} \\
\hline 層数 & \multicolumn{5}{|c|}{1} \\
\hline 層あたりの落下回数 & 42 & 84 & 125 & 167 \\
\hline 単位仕事量 $\mathrm{E}_{\mathrm{d}}\left[\mathrm{kJ} / \mathrm{m}^{3}\right]$ & 229 & 458 & 681 & 910 \\
\hline
\end{tabular}
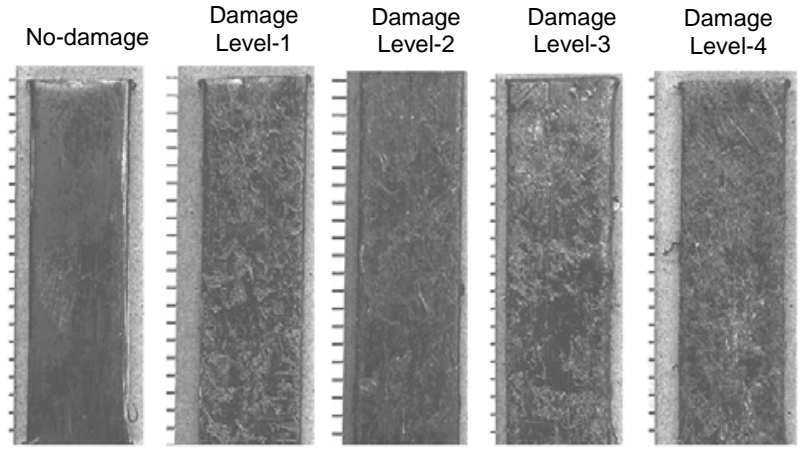

図-4＼cjkstart損傷の有無による補強材表面の違い

\section{（3）損傷供試体の準備方法と実験ケース}

損傷供試体は，粒状土中に HDPE ジオグリッドを配置 し締固め荷重を与えることで準備した. 粒状土として, 砂岩砕石 (最大粒径 $D_{\max }=9.5 \mathrm{~mm}$, 平均粒径 $D_{50}=4.5 \mathrm{~mm}$ ) を 用いた．締固めには，土の突き固め試験で用いるランマ 一(JIS A 1210 の A法，ランマー質量 $2.5 \mathrm{~kg}$ ) を用いた。 補 強材を上下 $5 \mathrm{~cm}$ の空気乾燥状態の砶層の中に配置し, 試験体幅 $9 \mathrm{~cm} \times$ 長さ $15 \mathrm{~cm}$ の領域に対してランマーを所 定の回数, 自由落下させて作製した. 損傷供試体の準備 条件を表-2 に示す. ランマーの落下回数は損傷レベル 1 , 2, 3 および 4 に対してそれぞれ 42 回，84 回，125 回お よび 167 回と設定した. 供試体を損傷させる締固めにお いては，試験中補強材の上部の土層厚さを一定にするよ うに努めた. 土の突き固め試験 JS A 1210 で定義されて いる締固め仕事量を参照して損傷に要した仕事量 $E_{\mathrm{d}}$ を 算出すると，損傷レベル 1，2，3，4 でそれぞれ 229，

458, 681, $910 \mathrm{~kJ} / \mathrm{cm}^{3}$ となる.

引張実験は，損傷なしの (No Damage)供試体と表-2 に 示した 4 種類の損傷レベルの供試体（Damage level-1 〜 4）の計 5 ケースに対して実施した. 各実験ケースでは, 有効データ数が 5 個になるよう複数回試験を実施した.

\section{（4）供試体の表面粗度解析}

前節で説明した方法で供試体を損傷させると，ジオグ リッドの表面は図-4 のように傷付く．この傷の程度が 損傷レベルを表す指標になると考え, 図-5 に示すよう な高精度 2 次元レーザ変位計(鉛直方向の分解能 $1 \mu \mathrm{n}$ ) を 用いて供試体の表面粗度を解析した。一連の作業では,

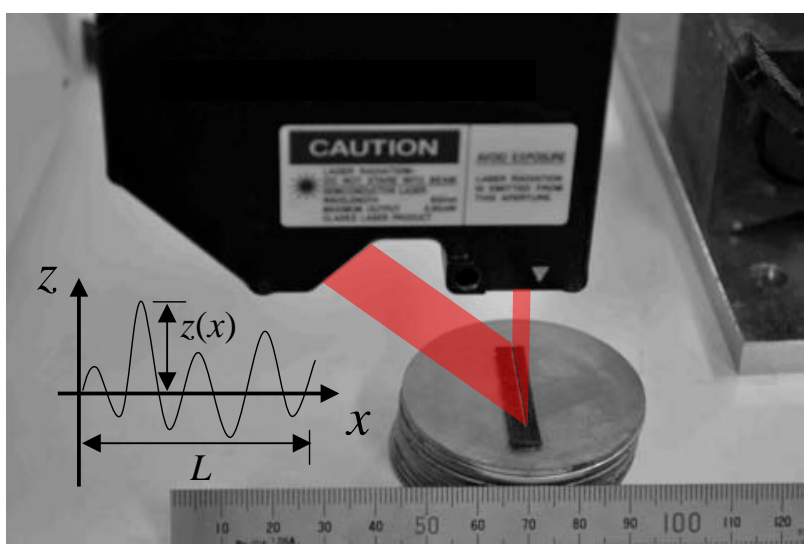

図-5 補強材の表面粗度計測

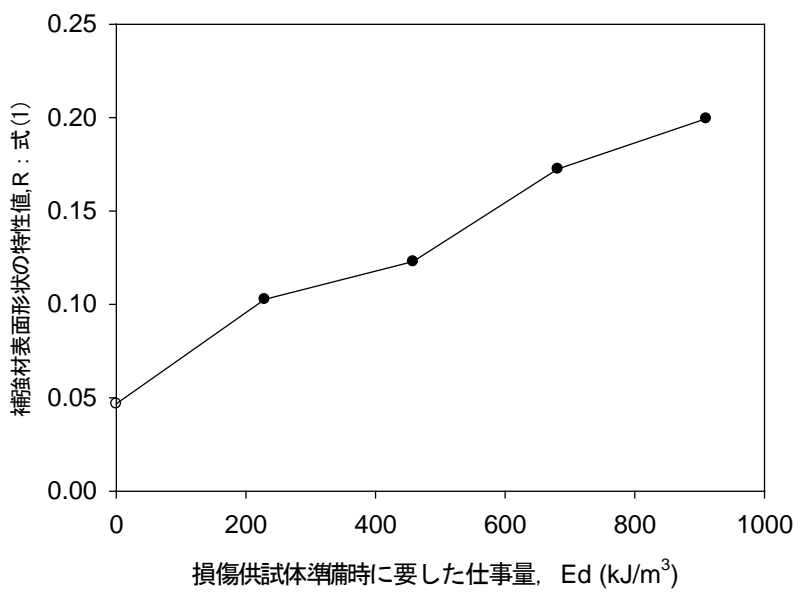

図-6 表面粗度の特性值と損傷供試体準備時の仕事量

まず損傷させた供試体を厚さ $1.5 \mathrm{~mm}$ の鉄板にひずみゲ ージ用ゲージセメントで貼り付けた．次に，レーザ変形 計で表面粗度を計測した。 この計測值に対し $x$ 方向の 平均值が 0 となるようにトレンド処理を行い，表面の相 対高さ $z$ を算出した. 最後に次式で表面粗度の特性值 $R$ を評価した。

$$
R=\frac{1}{L} \int_{0}^{L}|z(x)| d x
$$

このようにして算出した $R$ と，損傷供試体を準備する 際の締固め試験のエネルギーの関係を図一 6 に示寸。高 いエネルギーで締固めた方が表面の凹凸が大きくなるこ とが分かる.

\section{4. 損傷供試体を用いた引張試験結果}

損傷なし（No damage）と 4 段階の損傷レベル (Damage Level 1 4) における引張力 $T$ と伸びひずみ $\varepsilon$ の関係を図-7(a)〜 (e)に示寸。このようにして得られた $T-\varepsilon$ 曲線より図-8 に示寸方法で, 引張強度 $T_{y}, T_{\mathrm{y}}$ を発 揮時のひずみ 

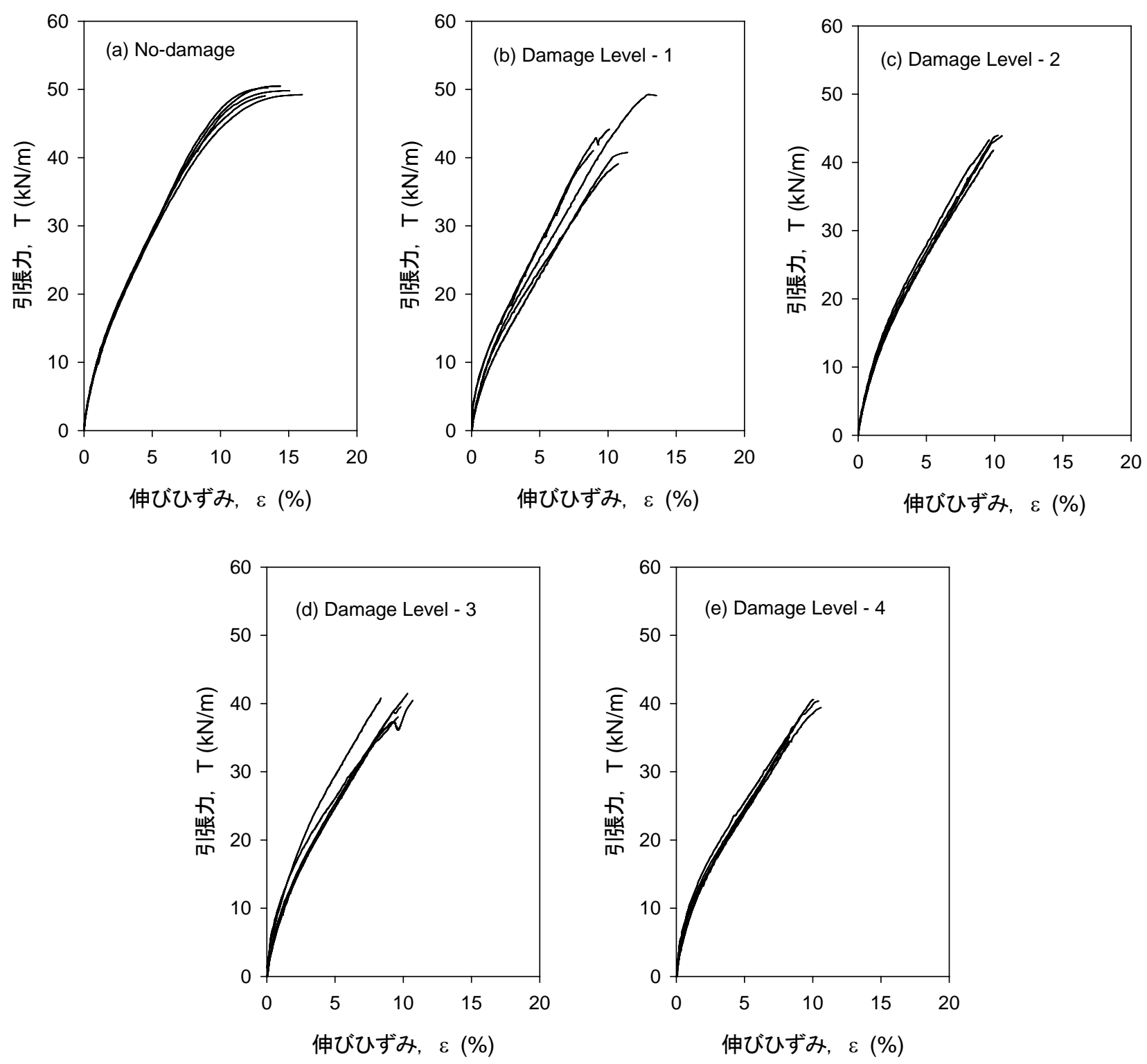

図-7 各損傷レベル供試体の引張力一伸びひずみ関係 （ピーク後の $\mathrm{T}-\varepsilon$ 関係は省略）

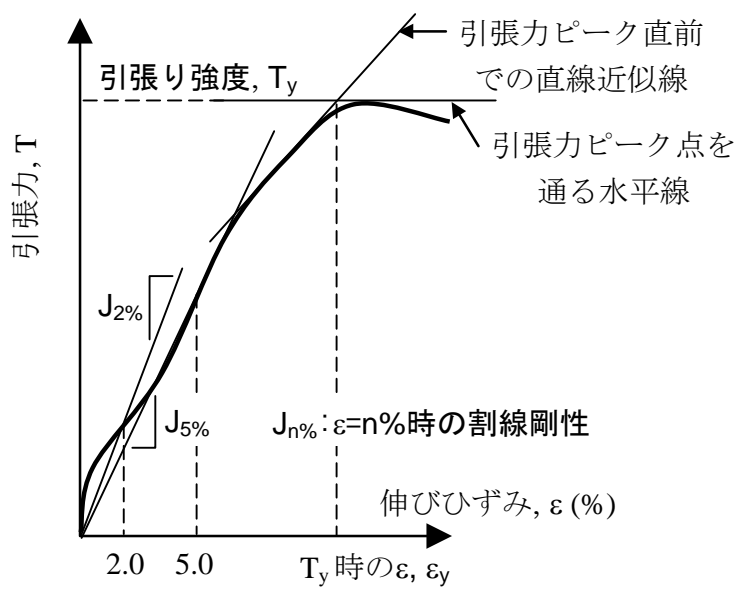

図-8 引張強度特性の評価法
の割線剛性 $J_{5 \%}$ を算出した. さらに，各ケースに次式を 用いて, 平均值の区間推定を行った.

$$
\bar{x} \pm t(\alpha / 2, n-1) \sqrt{\frac{V}{n}}
$$

ここで， $\bar{x}$ : 標本平均, $V$ : 標本不偏分散, $\alpha$ : 有意水 準, $n$ : データ数, $t$ : スチューデントの $t$ 分布の $t$ 值.

4 種類の引張強度特性の特性值と供試体の損傷レベ ルを表す表面損傷度指数 $S_{\mathrm{d}}$ の関係を図-9 に示す。ここ で， $S_{\mathrm{d}}$ は，損傷補強材の表面粗度の特性值 : 式(1)を損傷 なしのそれで除した指数である. また罒中の曲線は, 各 損傷レベルの標本平均を指数関数で近似した結果である.

図-9 より，引張強度に影響を及ぼす損傷レベルでも 割線剛性の変化はほとんど無視できることが分かる。そ して, 引張強度特性を表す各指標と $S_{\mathrm{d}}$ の関係は指数関 

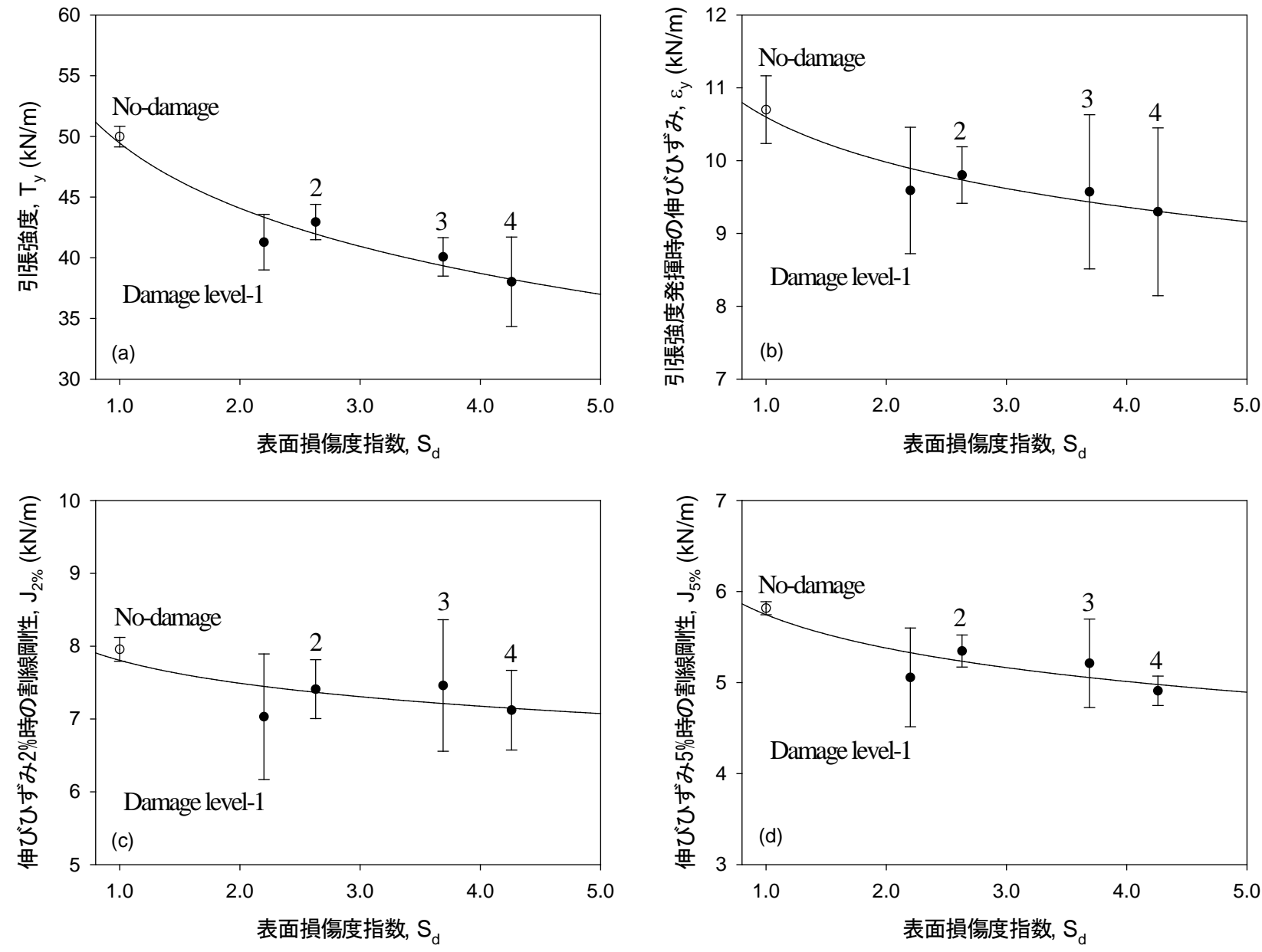

図-9＼cjkstart損傷レベルが HDPE ジオグリッドの引張強度特性に及ぼす影響

数でうまく近似できることが分かる.

今後， $S_{\mathrm{d}}$ が補強材の施工による損傷レベルを表すのに 適した指数であるのか，実際の現場でのどの程度の損傷 レベルなのか（すなわち， $S_{\mathrm{d}}$ がどの程度になっている か)， $S_{\mathrm{d}}$ と引張強度特性を表す各指標との関係が，現場 においても成り立つのか，などについて更なる検討が必 要である．また，この考え方が PP 補強材や樹脂系の補 強材にも適用できるかを検討する必要がある，それらの 検討をもとに，限界状態設計法における合理的な部分係 数の算定につなげたいと考えている.

\section{5. まとめ}

粒状土中にHDPEジオグリッドを配置し締固め荷重を 与えることで準備した損傷供試体の引張り強度特性を調 ベた．損傷レベルをレーザ変位計で測定した供試体の表 面粗度をもとに定量化し，損傷レベルがHDPEジオグリ ッドの引張強度特性の及ぼす影響を統計的に考察した。 引張強度特性を表す各特性值と提案する損傷指数は単純 な関数で近似しうることを示した。
謝辞

本研究は文部科学省科学研究費補助金基盤研究 (B)21360229（研究代表者 宮田喜壽）の助成を受けた. 供試体の提供を，弘中淳市氏（三井化学産資）より受け た. 記して感謝の意を表したい.

\section{参考文献}

1) American Association of State Highway and Transportation Officials: LRFD Bridge Design Specifications. AASHTO, Interims to Fourth Edition, Washington D.C., USA, 2009.

2) British Standards Institution: BS8006, Code of practice for strengthened/reinforced soil and other fills. BSI, Milton Keynes, United Kingdom, 1995.

3) Hong Kong Geotechnical Engineering Office: Geoguide 6, Guide to reinforced fill structure and slope design, Hong Kong, China, 2002.

4) 土木研究センター: ジオテキスタイルを用いた補強土の 設計・施工マニュアル 改訂版. Tsukuba, Japan, 2000.

5) WSDOT T925: Standard practice for determination of longterm strength for geosynthetic reinforcement. Washington State Department of Transportation, Washington, USA, 2005. 
6) Austin, R.A: The effect of installation activities and fire exposure on geogrid performance, Geotextile and Geomembranes 15 (4-6) 367-376, 1998.

7) Hong Kong Special Administrative Region: Certification of Reinforced Fill Products Submission Requirements, 2004.

8) Akagi, T., Chida, S., Yamamoto, C. and Miki, H: PWRC certification of geosynthetics. Proceeding of 4th Asian Regional Conference on Geosynthetics. Seoul, Korea. 363-368, 2004.

9) Allen, T.M. and Bathurst, R.J.: Characterization of geosynthetic load-strain behavior after installation damage, Geosynthetics International 1(2) 181-199, 1994.

10) Allen, T.M. and Bathurst, R.J.: Investigation of the combined allowable strength reduction factor for geosynthetic creep and installation damage, Geosynthetics International 3(3) 407-439, 1996.

11) Elias, V.: Corrosion/degradation of soil reinforcements for mechanically stabilized earth walls and reinforced soil slopes. Report FHWA-NH1-00-044, Federal Highway Administration, Washington DC, USA. 94 p., 2000.

12) Elias, V., Christopher, B., and Berg, R.: Mechanically stabilized earth walls and reinforced soil slopes design and construction guidelines. FHWA-NHI-00-043. Federal Highway Administration, Washington DC, USA, 394p, 2001.

13) Hufenus, R., Ruegger, R. Flum, D. and Sterba, I.J.: Strength reduction factors due to installation damage of reinforcing geosynthetics. Geotextile and Geomembranes 23(5) 401-424, 2005.

14) Huang, C.-C. and Chiou, S.-L.: Investigation of installation damage of some geogrids using laboratory tests. Geosynthetics International 13(1) 23-35, 2006.

15) Huang, C.-C.: Laboratory simulation of installation damage of a geogrid. Geosynthetics International. 13(3) 120-132, 2006.

16) ASTM D5818: Standard practice for exposure and retrieval of samples to evaluate installation damage of geosynthetics. American Society for Testing and Materials, West Conshohocken, PA, USA, 2006.

17) ISO 10722-1: Geosynthetics - Index test procedure for the evaluation of mechanical damage under repeated loading Damage caused by granular material. CEN, European Committee for Standardization, 2007.

\section{EFFECTS OF INSTALLATION-DAMAGE LEVEL ON TENSILE STRENGTH PROPERTIES OF HDPE GEOGRID}

\section{Takeshi MATSUNO, Yoshihisa MIYATA and Daiki HIRAKAWA}

Tensile strength properties of HDPE geogrid, which was damaged by compaction in sandwich with gravel, were investigated. Damage level was evaluated by surface roughness measured by a laser microscope, and deformation of tensile tests was evaluated by image analysis method. Effect of damage level on tensile strength properties is discussed statistically. Achievement of this paper will contribute for design strength evaluation of geogrid.

Keywords: geogrid, tensile strength property, installation damage 